\title{
Elevated seawater temperature causes a microbial shift on crustose coralline algae with implications for the recruitment of coral larvae
}

\author{
Nicole S Webster, Rochelle Soo, Rose Cobb and Andrew P Negri \\ Australian Institute of Marine Science, Townsville, Queensland, Australia
}

\begin{abstract}
Crustose coralline algae (CCA) are key reef-building primary producers that are known to induce the metamorphosis and recruitment of many species of coral larvae. Reef biofilms (particularly microorganisms associated with (CA) are also important as settlement cues for a variety of marine invertebrates, including corals. If rising sea surface temperatures (SSTs) affect CCA and/or their associated biofilms, this may in turn affect recruitment on coral reefs. Herein, we report that the CCA Neogoniolithon fosliei, and its associated microbial communities do not tolerate SSTs of $32{ }^{\circ} \mathrm{C}$, only 2-4 ${ }^{\circ} \mathrm{C}$ above the mean maximum annual SST. After 7 days at $32{ }^{\circ} \mathrm{C}$, the CCA exhibited clear signs of stress, including bleaching, a reduction in maximum quantum yield $\left(F_{\mathrm{v}} / F_{\mathrm{m}}\right)$ and a large shift in microbial community structure. This shift at $32{ }^{\circ} \mathrm{C}$ involved an increase in Bacteroidetes and a reduction in Alphaproteobacteria, including the loss of the primary strain (with high-sequence similarity to a described coral symbiont). A recovery in $F_{\mathrm{v}} / F_{\mathrm{m}}$ was observed in CCA exposed to $31{ }^{\circ} \mathrm{C}$ following 7 days of recovery (at $27^{\circ} \mathrm{C}$ ); however, CCA exposed to $32{ }^{\circ} \mathrm{C}$ did not recover during this time as evidenced by the rapid growth of endolithic green algae. A $50 \%$ reduction in the ability of $N$. fosliei to induce coral larval metamorphosis at $32^{\circ} \mathrm{C}$ accompanied the changes in microbiology, pigmentation and photophysiology of the CCA. This is the first experimental evidence to demonstrate how thermal stress influences microbial associations on CCA with subsequent downstream impacts on coral recruitment, which is critical for reef regeneration and recovery from climate-related mortality events.
\end{abstract}

The ISME Journal (2011) 5, 759-770; doi:10.1038/ismej.2010.152; published online 14 October 2010

Subject Category: microbial ecosystem impacts

Keywords: crustose coralline algae; biofilms; temperature; microbes; bleaching; coral settlement

\section{Introduction}

Larvae of numerous marine invertebrate species, including sponges, echinoderms, polychaetes, barnacles, molluscs, tunicates, bryozoans and cnidarians settle and metamorphose in response to bacterial biofilms (reviewed by Wieczorek and Todd, 1998). Coral larvae actively select their site of permanent attachment using chemical cues to induce metamorphosis (Morse et al., 1988, 1994, 1996; Heyward and Negri, 1999). The primary source of these chemical morphogens is various species of non-geniculate calcareous coralline algae (CCA). Bacterial biofilms occur on the surface of CCA (Galbary and Veltkamp, 1980; Garland et al., 1985; Lewis et al., 1985; Johnson et al., 1991) and also have a role in inducing larval metamorphosis for some invertebrates. A strain of Pseudoalteromonas,

Correspondence: NS Webster, Australian Institute of Marine Science, Microbiology and Symbiosis, PMB 3 Townsville Mail Centre, Townsville, Queensland 4810, Australia.

E-mail: n.webster@aims.gov.au

Received 27 May 2010; revised 23 July 2010; accepted 18 August 2010; published online 14 October 2010 isolated from CCA, is able to induce significant levels of metamorphosis of coral larvae (Acropora willisea and A. millepora) (Negri et al., 2001); numerous bacterial strains from CCA induce settlement of the sea urchin Heliocidaris erythrogramma (Huggett et al., 2006) and metamorphosis of crownof-thorns starfish larvae (Acanthaster planci) is also triggered by microorganisms associated with CCA (Johnson and Sutton, 1994).

Although it is well-established that settlement and recruitment of marine invertebrates varies with biotic and abiotic factors (hydrodynamics, light, temperature, gravity, surface texture and presence of conspecifics) (Rodriguez et al., 1993), little work has been done to test whether environmental variables affect the inductive ability of marine microbial biofilms. Biofilm age and depth can affect the inductive and inhibitory capacities of biofilms (Wieczorek and Todd, 1997; Webster et al., 2004), and localised anthropogenic impact can also shift the biofilm composition (Meyer-Reil and Koster, 2000; Lawrence et al., 2004) and potentially influence subsequent invertebrate recruitment (Webster et al., 2006). However, to date no research has addressed how variables associated with a changing 
climate (elevated sea-surface temperature (SST), ocean acidification and eutrophication) will affect the inductive ability of marine microbial biofilms.

The potential impacts of climate change on marine microorganisms are rarely assessed, despite the critical contribution of microbes to marine biomass, diversity and ecosystem function. One of the primary effects of climate change is a projected $1.8-4{ }^{\circ} \mathrm{C}$ increase in global air temperature by 2100 , along with similar rises in SST (range of best estimates from the six emissions marker scenarios of Special Report on Emission Scenarios (SRES)) (IPCC, 2007). Elevated sea temperatures could significantly impact on marine microbes, potentially altering microbial diversity, function and community dynamics (Webster and Hill, 2007). Elevated SST may affect recruitment in a number of ways: (1) by altering the ability of microbes to produce morphogenic signalling compounds, or (2) by causing a shift in the community composition and microbial succession of the biofilm, which may adversely (or positively) affect subsequent recruitment of macro-organisms, including corals. These outcomes could have serious implications for reefbuilding, maintenance and recovery processes. Environmental conditions that adversely affect the distribution and abundance of microbes involved in settlement and metamorphosis of reef invertebrates could therefore have large-scale impacts on ecosystem structure and the distribution and reproductive fitness of some keystone species.

Owing to the importance of both inert (sedimentassociated) and CCA-associated biofilms in the recruitment of coral larvae, this study aimed to (1) investigate the impact of elevated SST on the microbial biofilms of CCA and reef sediments and (2) assess whether the ability of CCA to induce metamorphosis in coral larvae can be affected by exposure to elevated SST.

\section{Materials and methods}

Sample collection and temperature exposure

Fragments of the crustose coralline algae Neogoniolithon fosliei $(8 \times 8 \mathrm{~cm})$ and $1 \mathrm{~kg}$ of surface sediments were collected between 5-8 $\mathrm{m}$ at Davies Reef $\left(19^{\circ} 09\right.$. $\left.35^{\prime} \mathrm{S} ; 146^{\circ} 52.87^{\prime} \mathrm{E}\right)$, Queensland, Australia in October 2008. The upper $2 \mathrm{~cm}$ of reef sediments were scraped into glass beakers using a sterile spatula. All samples were transported in flowing seawater to the indoor temperature-controlled aquarium at the Australian Institute of Marine Science, Townsville, Australia. CCA discs of identical size were prepared using a $20-\mathrm{mm}$ diamond hole saw.

The experimental design incorporated four temperatures $\left(27^{\circ} \mathrm{C}, 29^{\circ} \mathrm{C}, 31^{\circ} \mathrm{C}\right.$ and $32^{\circ} \mathrm{C}$; range $\pm 0.2^{\circ} \mathrm{C}$ ) in three replicate 30 -l flow-throughs $\left(600 \mathrm{ml} \mathrm{min}^{-1}\right)$ aquaria per temperature. Sampling times were $\mathrm{T}=0$ day (all treatments at $27^{\circ} \mathrm{C}$ ), $\mathrm{T}=1$ day, $\mathrm{T}=2$ days, $\mathrm{T}=7$ days and $\mathrm{T}=14$ days. Temperatures were maintained for the first 7 days and then all temperatures were returned to $27^{\circ} \mathrm{C}$ for the final 7 days of the experiment as a recovery period. In each tank, there were $6 \times 6$ wells, 12 -ml cell-culture plates (Iwaki, Japan) with three wells per plate containing reef sediment at $6 \mathrm{~mm}$ depth and the other three wells containing the CCA discs. An individual six-well plate was randomly removed per tank at each time point (nine total replicates per temperature at each time for each CCA and sediment). Incoming seawater was filtered to $1 \mu \mathrm{m}$. All samples were maintained under a diel cycle of $(12: 12 \mathrm{~h})$ at $80 \mu \mathrm{mol}$ quanta $\mathrm{m}^{-2} \mathrm{~s}^{-1}$, reflecting light intensity at $8 \mathrm{~m}$ on the reef. Initially, all aquaria were left at $27^{\circ} \mathrm{C}$ for $72 \mathrm{~h}$ and then temperatures were adjusted gradually $\left(0.15^{\circ} \mathrm{Ch}^{-1}\right)$ until reaching the final temperatures (at $\mathrm{T}=0$ day).

At each time point all CCA and sediment samples were photographed and frozen in liquid nitrogen for molecular analysis. Seawater samples (11) from each temperature at each time point were filtered through a $0.2-\mu \mathrm{m}$ sterivex filter (Durapore, Millipore, North Ryde, New South Wales, Australia), which were filled with $1.8 \mathrm{ml}$ of lysis buffer ( $40 \mathrm{mM}$ EDTA (pH 8.0 ), $50 \mathrm{~mm}$ Tris and $0.75 \mathrm{M}$ sucrose) and frozen at $-80^{\circ} \mathrm{C}$.

Thermal stress can result in the loss of pigments (bleaching) in CCA (Anthony et al., 2008). Damage to photosystem II (PSII) of CCA was assessed using pulse amplitude modulation fluorometry. Fluorescence measurements were taken following a 30-min dark adaptation period using a Mini-PAM fluorometer (Walz, Effeltrich, Germany) by placing a 6-mm fibre-optic probe perpendicular to the centre of the CCA discs. Initial fluorescence $\left(F_{0}\right)$ was determined by applying a weak pulse-modulated red-measuring light $\left(0.15 \mu \mathrm{mol}\right.$ photons $\left.\mathrm{m}^{-2} \mathrm{~s}^{-1}\right)$. To quantify maximum fluorescence $\left(F_{\mathrm{m}}\right)$, a short pulse $(800 \mathrm{~ms})$ of saturating actinic light $(>3000 \mu \mathrm{mol}$ photons $\mathrm{m}^{-2} \mathrm{~s}^{-1}, 650 \mathrm{~nm}$ ) was applied (Jones et al., 2003). Maximum quantum yield $\left(F_{\mathrm{v}} / F_{m}\right)$ of photochemical energy conversion in PSII was calculated based on $F_{0}$ and $F_{\mathrm{m}}$ as per Equation (1) (Genty et al., 1989).

$$
F_{\mathrm{v}} / F_{\mathrm{m}}=\left(F_{\mathrm{m}}-F_{0}\right) / F_{\mathrm{m}}
$$

a reduction in $F_{\mathrm{v}} / F_{\mathrm{m}}$ indicates damage to the D1 protein in PSII (Osmond et al., 1999).

\section{Coral metamorphosis assays}

Larvae were raised from gametes collected from live colonies of the reef-building coral $A$. millepora (Ehrenberg, 1834). Corals were collected by snorkelling from a depth of 6-8 $\mathrm{m}$ on a fringing reef of Pelorus Island, Great Barrier Reef (GBR) (18 $32 \mathrm{~S}$, $146^{\circ} 29 \mathrm{E}$ ) and transported to flow-through aquaria at the Australian Institute of Marine Science. Synchronous spawning occurred on 14 November 2008, and the released gametes, in the form of buoyant egg-sperm bundles, were cross-fertilised as described in Negri and Heyward (2000). Larvae were raised in a 500-l plastic tank with flowing $1 \mu \mathrm{m}$-filtered seawater at $27^{\circ} \mathrm{C}$. Larval metamorphosis 
assays were performed in 10-cm diameter sterile plastic petri dishes maintained at $28{ }^{\circ} \mathrm{C}$. Coral larvae (8 days old) $(n=10-20)$ were introduced to each dish containing a single CCA disc that had been exposed to each of the treatment temperatures for 7 days and seawater was added to a final volume of $30 \mathrm{ml}$. Larvae were defined as metamorphosed when they had changed from either free-swimming or casually-attached pear-shaped forms to squat, firmly-attached disk-shaped structures with pronounced flattening of the oral-aboral axis and typically obvious septal mesenteries radiating from the central mouth region (Heyward and Negri, 1999). A time period of $24 \mathrm{~h}$ was chosen as the end point for scoring early-stage metamorphosis.

\section{Denaturing gradient gel electrophoresis}

Frozen CCA tissue and reef sediments (approximately $0.5 \mathrm{~g}$ per sample) were aseptically transferred to $1.5 \mathrm{ml}$ Eppendorf tubes using sterile scalpels. Grinding buffer $(0.5 \mathrm{ml})$ was added to each replicate sample (100 mM Tris (pH 9.0), $100 \mathrm{mM}$ EDTA ( $\mathrm{pH}$ 8.0), 1\% SDS and $100 \mathrm{mM} \mathrm{NaCl}$ ). Tubes were immersed in liquid nitrogen and ground with plastic pestles. Samples were incubated at $65^{\circ} \mathrm{C}$ for $60 \mathrm{~min}$ before addition of $187 \mu \mathrm{l} 5 \mathrm{M}$ potassium acetate. Samples were incubated on ice for $30 \mathrm{~min}$ and centrifuged at $8000 \mathrm{~g}$ for $15 \mathrm{~min}$. The supernatants were transferred to fresh tubes and DNA was precipitated with $0.8 \mathrm{vol}$ of isopropanol. DNA was extracted from seawater filters by addition of $200 \mu \mathrm{l}$ lysozyme $\left(10 \mathrm{mg} \mathrm{ml}^{-1}\right)$, incubation at $37^{\circ} \mathrm{C}$ for $45 \mathrm{~min}$, addition of $200 \mu \mathrm{l}$ of proteinase $\mathrm{K}$ $\left(0.2 \mu \mathrm{g} \mathrm{ml}^{-1}\right)$ and $1 \%$ SDS and incubation at $55{ }^{\circ} \mathrm{C}$ for $1 \mathrm{~h}$. Lysates were recovered into fresh eppendorf tubes and DNA was extracted with a standard phenol:chloroform:isoamyl alcohol procedure and precipitated with $0.8 \mathrm{vol}$ of isopropanol.

The 16S rRNA gene from each CCA disc, sediment and seawater sample was amplified by PCR with primers 1055f and 1406r (Ferris et al., 1996). PCR reactions were performed as described by Ferris et al. (1996) and products from duplicate PCR reactions were combined and $15 \mu \mathrm{l}$ applied to $8 \%$ w/v polyacrylamide (37.5:1) gels containing a $50-70 \%$ denaturing gradient of formamide and urea. Gels were electrophoresed at $60^{\circ} \mathrm{C}$ for $17 \mathrm{~h}$ in $1 \times$ TAE buffer at $50 \mathrm{~V}$ using the Ingeny D-Code system (Amundsenweg, The Netherlands) and stained with $1 \times$ Sybr Gold for $30 \mathrm{~min}$, visualised under UV illumination and photographed. The denaturing gradient gel electrophoresis (DGGE) banding profiles using these universal 16S rRNA gene primers could not be resolved with the CCA and sediment samples because of extreme bacterial diversity producing a smear of bands on the gels. Additional DGGE-PCR was conducted for the CCA samples with primers rpoB1698f and rpoB2041r specific to the $r p o B$ gene (Dahllöf et al., 2000), F203 $\alpha$ with $788 \mathrm{R}$ to amplify the $16 \mathrm{~S}$ rRNA gene from the
Alphaproteobacteria (Gelsomino and Cacco, 2006; Huys et al., 2008) and CFB319 with 788R to amplify the 16S rRNA gene from the Cytophaga-FlavobacteriaBacteroidetes group (Fierer et al., 2005; Huys et al., 2008). The reverse primers rpoB2041 and 788R were modified to incorporate the GC clamp as per Ferris et al. (1996). DGGE analysis was performed as described above and band analysis was performed on Fragment NT Version 1.1a (Quantity One, Bio-Rad Laboratories Pty Ltd., Gladesville, New South Wales, Australia). Individual band numbers were assigned based on the bands migration relative to control bands. Bands assigned the same number had identical migration end points. Bands that did not migrate to the same point on duplicate gels were not considered in subsequent analyses.

The 18S rRNA gene from each CCA sample was also amplified by PCR with universal eukaryotic primers as follows: NS1f, 5'-GTAGTCATATGCTTG TCTC-3' and NS2r, 5'-GGCTGCTGGCACCAGACTT GC-3' (White et al., 1990). The PCR and DGGE were performed as described above with the exception that the products were electrophoresed on a $35-70 \%$ denaturing gradient.

\section{D rRNA gene cloning and sequencing}

For a more comprehensive phylogenetic comparison between the different temperatures, the $16 \mathrm{~S}$ rRNA gene from each CCA disc sampled at 2- and 7 day was amplified by PCR with primers $63 \mathrm{f}$ and $1387 \mathrm{r}$ (Marchesi et al., 1998). The PCR products were combined for all replicate CCA discs per temperature at each time point. To assess whether biotic (CCA) and abiotic (sediment) biofilms responded differently to elevated temperature, the sediment samples at $27^{\circ} \mathrm{C}$ and $32^{\circ} \mathrm{C}$ were also collected at 2- and 7 day and assessed by 16S rRNA gene sequence analysis. PCR products were ligated into the TOPO TA cloning vector (Invitrogen Australia Pty Ltd., Mulgrave, Victoria, Australia). Ligations were sent to the Australian Genome Research Facility (University of Queensland, Brisbane) for transformation and sequencing of 192 clones for each CCA library and 96 clones for each sediment library. Australian Genome Research Facility transformed the ligations into Genehog electrocompetent cells (Invitrogen), grew the cells in $2 \times \mathrm{YT}+$ ampicillin media, performed a standard alkaline lysis plasmid preparation and sequenced the clones with ABI Bigdye v3.1 chemistry on the AB3730xl (standard 50-cm array run module; Mulgrave, Victoria, Australia). Clone sequences were submitted to the Genbank under the accession numbers HM177481 to HM178920.

\section{Phylogenetic analysis}

Clone sequence quality was checked manually using Sequencher (Genesearch, Brisbane, Queensland, Austraila). Chimeric sequences were identified using the programs CHECK_CHIMERA (Maidak et al., 
1999) and Bellerophon (Huber et al., 2004). Sequences were imported into the ARB software package (http://www.arb-home.de) (Ludwig et al., 1998), automatically aligned using FastAligner and manually edited. Phylogenetic trees were calculated with almost complete 16S rRNA (1400 bp) sequences for all the close relatives of target sequences using the neighbour-joining and maximum parsimony methods in ARB. Partial sequences were subsequently imported to the tree without changing branch topology using the ARB parsimony-interactive method. The robustness of inferred tree topologies was evaluated after 1000 bootstrap resamplings of the neighbour-joining data in the Phylip program (Felsenstein, 1993).

\section{Data analyses}

Clone sequence results were visualised as phyla level pie charts to assess the phylogenetic affiliation of the shifting microbes and heat maps were constructed at a $97 \%$ sequence similarity level to reveal the extent of operational taxonomic unit (OTU) differences between the libraries.

The variability in percentage of coral metamorphosis on CCA at each temperature treatment was assessed using one-way analysis of variance (Statistica 6.0, StatSoft, Tulsa, OK, USA).

Principal components analysis was performed to analyse similarity in microbial community composition using DGGE data (Statistica 6.0, StatSoft). Matrices were constructed separately for the $r p o B$ gene DGGE, the combined analysis of the Alphaproteobacteria and Cytophaga-Flavobacteria-Bacteroidetes DGGE gels, the eukaryotic DGGE gel and the seawater 16SrRNA DGGE gel using the presence (1) or absence (0) of a band in each sample.

Pie charts were constructed using the phylogenetic assignments produced in ARB and plotted using Sigmaplot (v7.101, SPSS).

Distance matrices were generated in ARB by using Jukes-Cantor correction and OTU assignments; rarefaction curves and diversity estimates were produced in DOTUR using a distance of 0.03 (Schloss and Handelsman, 2005). Statistical analysis for CCA and sediment libraries were performed on the genetic distance matrices using LIBSHUFF (Schloss et al., 2004) to determine whether variability in library composition between treatments was because of chance or a real biological effect. OTU heat maps were constructed using a log2 scale in MOTHUR version 1.8.1 (Schloss et al., 2009). A community Newick-formatted tree with a distance of 0.03 was produced for the CCA libraries using MOTHUR version 1.8.1 according to the Yue and Clayton theta structural diversity measure.

\section{Results}

Elevated SST resulted in visible CCA bleaching (Figure 1) and a corresponding reduction in maximum quantum yield $\left(F_{\mathrm{v}} / F_{\mathrm{m}}\right)$ in CCA at $31^{\circ} \mathrm{C}$ and $32{ }^{\circ} \mathrm{C}$ (Figure 2). A subsequent increase in $F_{\mathrm{v}} / F_{\mathrm{m}}$ was observed when CCA treated at $31^{\circ} \mathrm{C}$ was returned to $27^{\circ} \mathrm{C}$ after 7 days. The CCA discs treated at $32{ }^{\circ} \mathrm{C}$ for 7 days (Figure 1c) developed a green shade under the surface during recovery, indicating colonisation by endolithic green algae. The $F_{\mathrm{v}} / F_{\mathrm{m}}$ values were not compared with the $32^{\circ} \mathrm{C}$ discs during recovery, as these endolithic algae would have contributed to the fluorescence responses. Live CCA discs treated at $27^{\circ} \mathrm{C}$ for 7 days induced settlement and metamorphosis of $93 \pm 2 \%$ of coral larvae (Figure 3). This level of metamorphosis was consistent for CCA treated at $29^{\circ} \mathrm{C}$ and $31{ }^{\circ} \mathrm{C}$, but dropped significantly (to $58 \pm 2 \%$ ) for heavily bleached CCA exposed to $32{ }^{\circ} \mathrm{C}$ for 7 days $(P<0.01$, ANOVA $\mathrm{F}_{3,2.05}=15.3$ ).

Screening of the CCA microbial communities by DGGE with universal 16S rRNA gene primers was not possible because of the high microbial diversity, which resulted in banding patterns too dense and complex for adequate resolution. Conversely, screening of the CCA microbial communities by DGGE with $r p o B$ gene primers showed no distinct clustering because of temperature treatment (Figure 4; Supplementary Figure 1). However, more detailed community analysis using 16S rRNA clone libraries revealed a distinct shift in the CCA microbial community composition at the phyla/ class level at $32{ }^{\circ} \mathrm{C}$ after 7 days (Figure 5a). Sediment biofilms, on the other hand, exhibited no obvious community differences between the two temperature extremes (Figure 5b). The $32{ }^{\circ} \mathrm{C}$ CCA libraries were dominated by Bacteroidetes with a lesser abundance of Alpha-, Gamma- and Deltaproteobacteria (Figure 5a). All other CCA libraries were dominated by Alphaproteobacteria, with a moderate abundance of Bacteroidetes and a low abundance of all other phyla. The sediment biofilms all contained high proportions of Alpha and Gammaproteobacteria and moderate abundances of Deltaproteobacteria, Bacteroidetes, Cyanobacteria, Firmicutes and 'other' comprising the Chloroflexi, Nitrospira and Actinobacteria (Figure 5b).

LIBSHUFF statistical analysis of the libraries revealed a highly significant difference between the 2- and 7-day $32{ }^{\circ} \mathrm{C}$ CCA libraries and all other temperature treatments (Table 1) and confirmed that there was no significant difference between any of the sediment biofilm treatments $(P>0.01)$. Although the 2-day CCA library at $31^{\circ} \mathrm{C}$ was significantly different to the 2-day CCA libraries from $27^{\circ} \mathrm{C}$ and $29^{\circ} \mathrm{C}$, respectively; the 7-day CCA library at $31^{\circ} \mathrm{C}$ was only significantly different to the $27^{\circ} \mathrm{C}$ library at 7 days. The community composition identified in the $27^{\circ} \mathrm{C}$ libraries for 2 - and 7 day were also found to be statistically different to all other communities (Table 1).

To assess the differences in community composition at a higher level of phylogenetic resolution, heat maps were constructed based on an OTU 


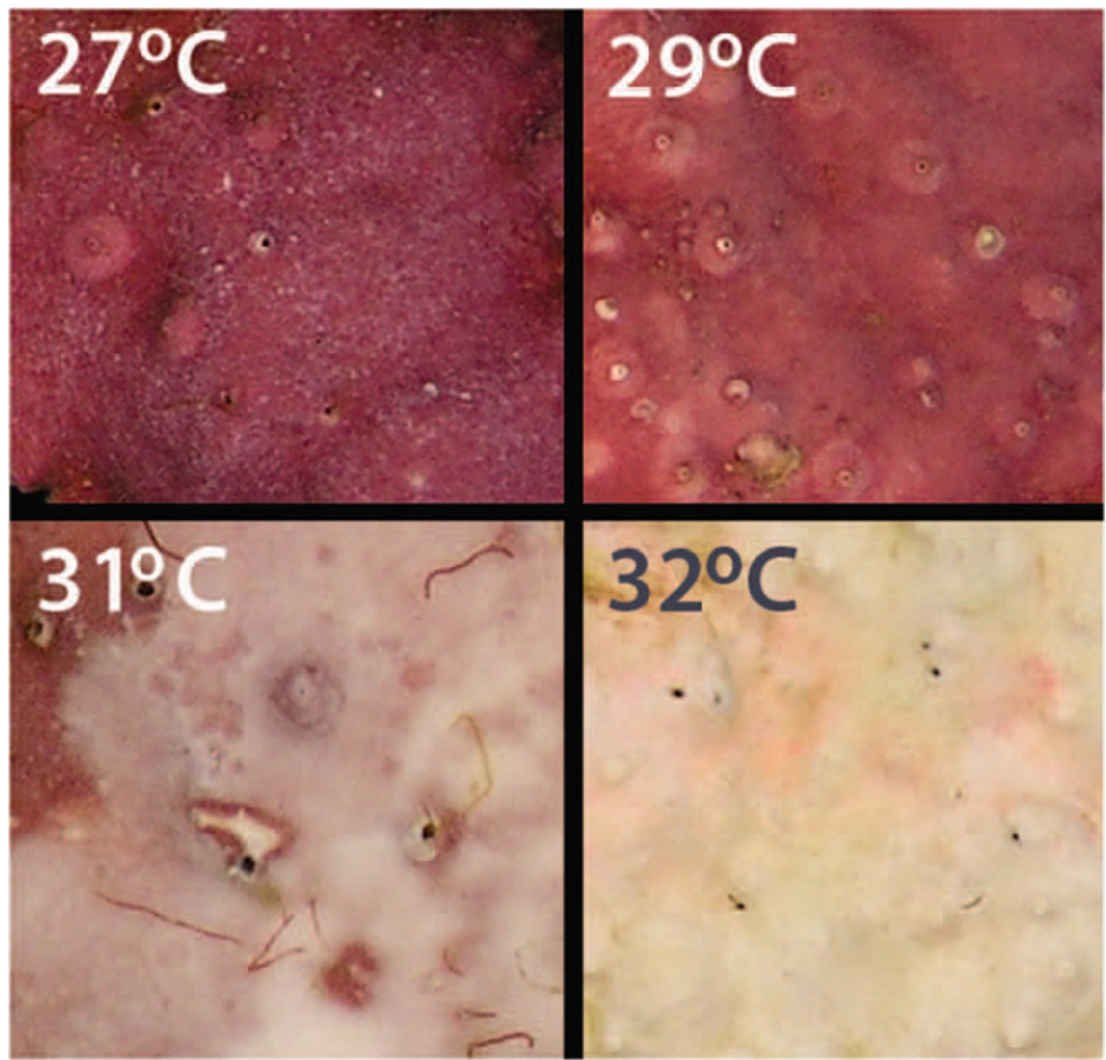

Figure 1 Photographic panel of CCA after 7 days at each of the experimental temperature treatments showing loss of pigment at $31{ }^{\circ} \mathrm{C}$ and complete bleaching at $32^{\circ} \mathrm{C}$.

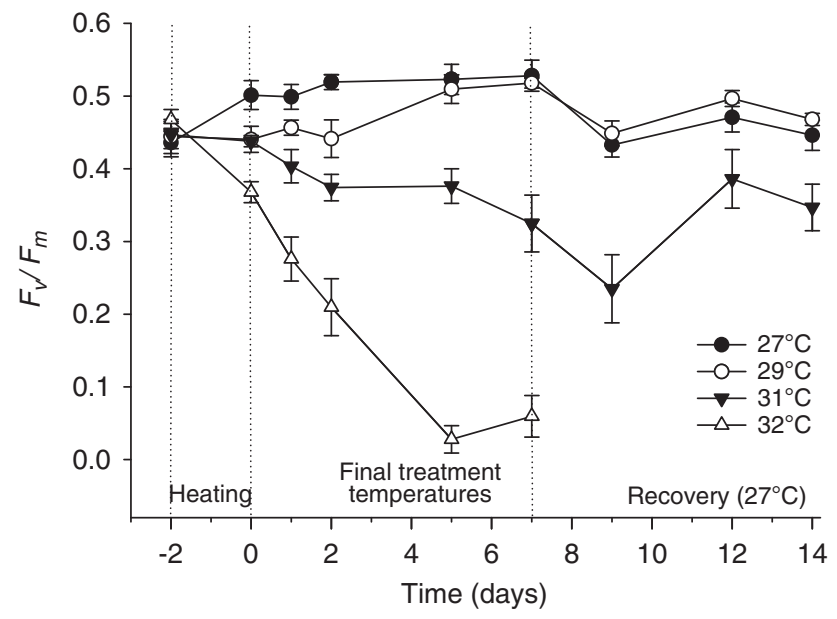

Figure 2 Maximum potential quantum yield $\left(F_{\mathrm{v}} / F_{\mathrm{m}}\right)$ of CCA in each temperature treatment during the 7 days exposure and subsequent 7 days recovery period.

assignment at a species-level (97\%) sequence-similarity threshold (Figure 6). Although the heat map of OTUs revealed some variability within most of the CCA libraries, the 7 -day $32{ }^{\circ} \mathrm{C}$ treatment was a clear outlier (Figure 6a). In contrast, much less variability was detected between the sediment biofilm communities exposed to the two temperature extremes after both 2 and 7 days (Figure 6b). Subsequent

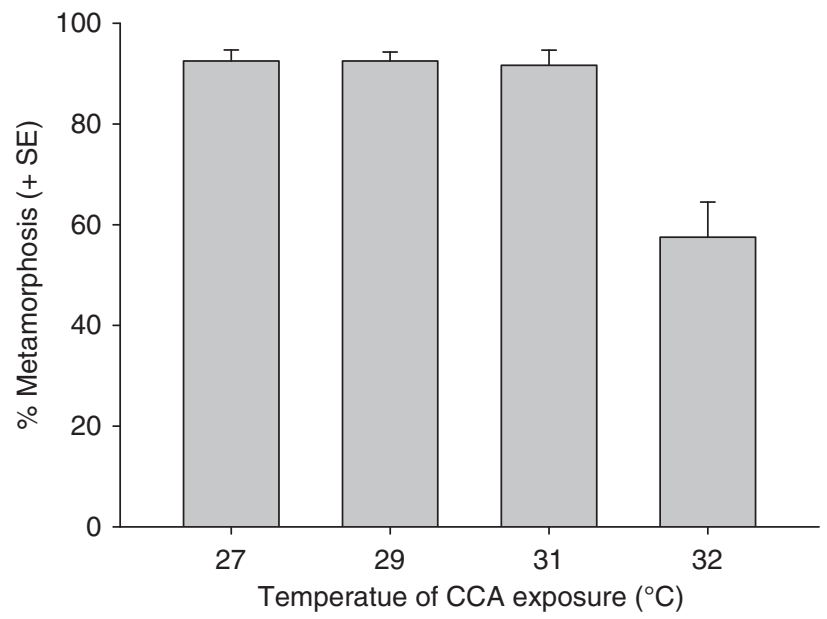

Figure 3 Percent metamorphosis of coral larvae on CCA that had been treated at $27^{\circ} \mathrm{C}, 29^{\circ} \mathrm{C}, 31^{\circ} \mathrm{C}$ and $32^{\circ} \mathrm{C}$ for 7 days.

analysis of the CCA biofilm community phylogenetic tree in ARB revealed three major differences between the 7 -day $32^{\circ} \mathrm{C}$ treatment and all other libraries. First, there was a loss of an Alphaproteobacteria (HM177926), which made up $30 \%$ of the sequences from the 2-day $32{ }^{\circ} \mathrm{C}$ library, but only $0.6 \%$ of the sequences from the 7 -day $32{ }^{\circ} \mathrm{C}$ library. This strain dominated all the other CCA libraries 
at both time points and had closest sequence similarity (96\%) to a symbiont from the coral Montastrea faveolata (accession number FJ202556,

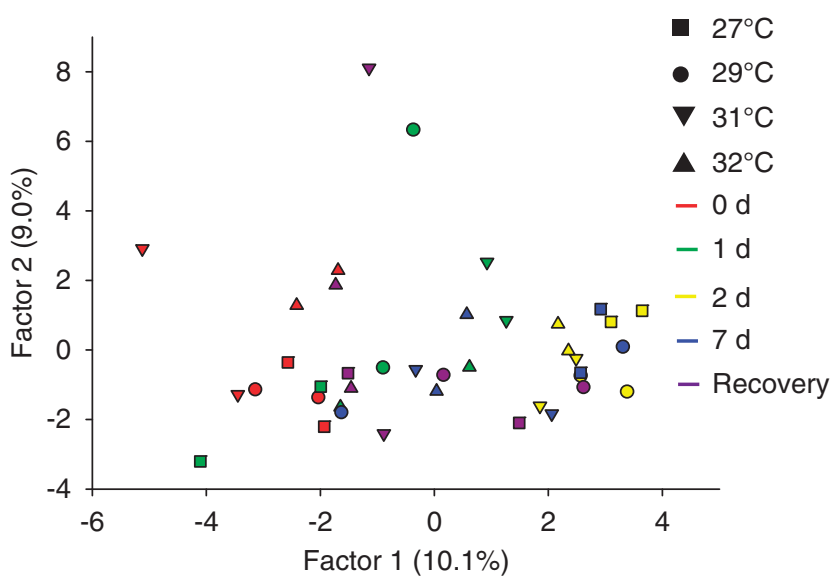

Figure 4 Principal components analysis of CCA bacterial community composition at each of the temperature treatments. DGGE banding pattern data generated with $r p o B$ gene primers was used to construct a similarity matrix.
(Sunagawa et al., 2010). The second difference was the appearance of a Deltaproteobacteria (HM178559), which was absent from all other libraries but made up $8 \%$ of the sequences from the 7 -day $32{ }^{\circ} \mathrm{C}$ library and had highest similarity $(98 \%)$ to a Desulfovibrio from a study of healthy and diseased corals (accession number FJ425598). The third major difference was a substantial increase in the abundance of a Bacteroidetes strain (HM178650) with $99 \%$ sequence similarity to a Flavobacterium (accession number AB270586). This strain made up $39 \%$ of the total sequences from the 7 -day $32{ }^{\circ} \mathrm{C}$ library, but only $0.5 \%$ and $1.6 \%$ of the 2 -day $32{ }^{\circ} \mathrm{C}$ and 7-day $27^{\circ} \mathrm{C}$ libraries, respectively.

To further visualise the similarity between CCA biofilm communities at different SSTs, a community tree was constructed based on an OTU assignment at a $97 \%$ sequence-similarity threshold (Figure 7). The tree demonstrates the clear differentiation of the CCA exposed to $32{ }^{\circ} \mathrm{C}$ for 7 days. This analysis also reveals that the 7 -day $31{ }^{\circ} \mathrm{C}$ and 2 -day $32{ }^{\circ} \mathrm{C}$ biofilms cluster together and apart from the biofilms exposed to lower temperatures. a
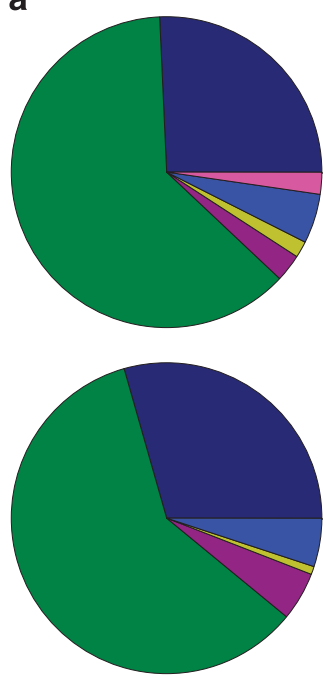

$27^{\circ} \mathrm{C}$

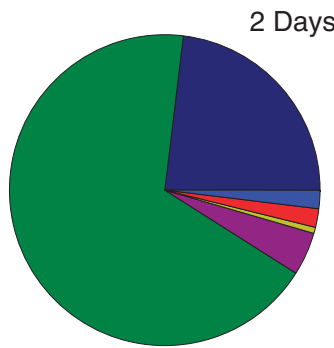

7 Days CCA

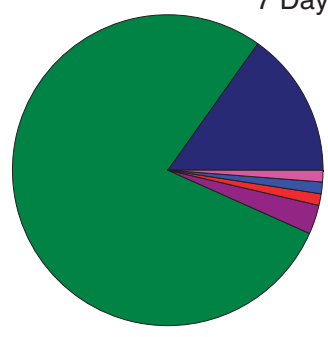

$29^{\circ} \mathrm{C}$
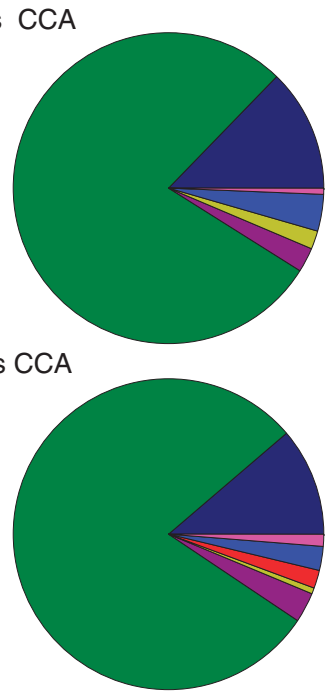

$31^{\circ} \mathrm{C}$
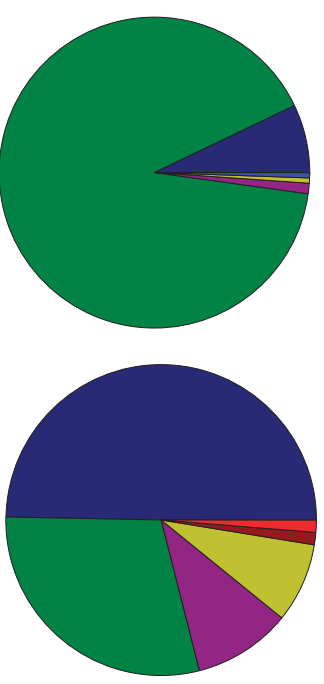

$32^{\circ} \mathrm{C}$

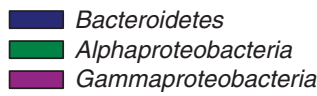

$\square$ Deltaproteobacteria

Epsilonproteobacteria Firmicutes

Tennericutes

b

2 Days Sediment

7 Days Sediment

$27^{\circ} \mathrm{C}$

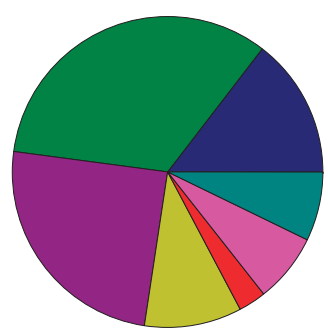

$32^{\circ} \mathrm{C}$

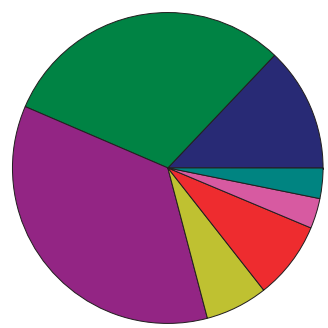

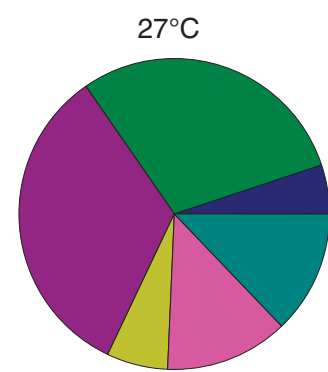

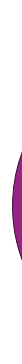

$32^{\circ} \mathrm{C}$

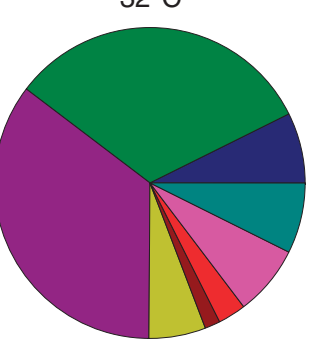

Figure 5 Phyla and class-level differences in bacterial biofilm composition on CCA (a) and reef sediment (b) at each temperature treatment. The 'other' category contains sequences from the Chloroflexi, Nitrospira and Actinobacteria phyla. Graphs were constructed using the frequency of $16 \mathrm{~s}$ rRNA sequences belonging to each bacterial group from clone library analysis. 
Table 1 LIBSHUFF analysis of variability in CCA clone library community composition

\begin{tabular}{|c|c|c|}
\hline Library comparison & Significance & Notes \\
\hline \multicolumn{3}{|l|}{ Time 2 days } \\
\hline $27^{\circ} \mathrm{C}$ vs ALL 2 days & $P<0.002$ & $\begin{array}{c}\mathrm{T} 2 \text { days } 29^{\circ} \mathrm{C} \\
\text { subset of } \mathrm{T} 2 \text { days } \\
27^{\circ} \mathrm{C}(P>0.01)\end{array}$ \\
\hline $\begin{array}{l}29^{\circ} \mathrm{C} \text { vs } 31^{\circ} \mathrm{C} \\
32^{\circ} \mathrm{C} \text { vs ALL } 2 \text { days }\end{array}$ & $\begin{array}{l}P=0.002 \\
P<0.0002\end{array}$ & \\
\hline \multicolumn{3}{|l|}{ Time 7 days } \\
\hline $27^{\circ} \mathrm{C}$ vs ALL 7 days & $P<0.001$ & $\begin{array}{c}\mathrm{T} 7 \text { days } 29^{\circ} \mathrm{C} \\
\text { subset of } \mathrm{T} 7 \text { days } \\
27^{\circ} \mathrm{C}(P>0.01)\end{array}$ \\
\hline $32{ }^{\circ} \mathrm{C}$ vs ALL 7 days & $P=0.0001$ & \\
\hline \multicolumn{3}{|l|}{ Between time } \\
\hline 7 days $27^{\circ} \mathrm{C}$ vs ALL 2 days & $P=0.0001$ & \\
\hline 7 days $29^{\circ} \mathrm{C}$ vs 2 days $32^{\circ} \mathrm{C}$ & $P=0.0001$ & \\
\hline 7 days $31^{\circ} \mathrm{C}$ vs 2 days $29^{\circ} \mathrm{C}$ & $P<0.001$ & \\
\hline 7 days $31^{\circ} \mathrm{C}$ vs 2 days $32^{\circ} \mathrm{C}$ & $P=0.0001$ & $\begin{array}{c}\mathrm{T} 2 \text { days } 32^{\circ} \mathrm{C} \\
\text { subset of } \mathrm{T} 7 \text { days } \\
31^{\circ} \mathrm{C}(P>0.01)\end{array}$ \\
\hline 7 days $32^{\circ} \mathrm{C}$ vs ALL 2 days & $P=0.0001$ & \\
\hline
\end{tabular}

Abbreviations: ALL, all other treatments; CCA, crustose coralline algae; $\mathrm{T}$, time.

Only statistically significant comparisons are shown.

**No significant differences were detected between any of the four sediment libraries.

To verify the species-level shift detected in CCA clone library analysis, additional DGGE was conducted using primers specific to the Alphaproteobacteria and Bacteroidetes groups (Supplementary Figures 3 and 4). Principle components analysis of these DGGE profiles revealed clear separation of the $27^{\circ} \mathrm{C}$ and $29^{\circ} \mathrm{C}$ libraries from the 0- and the 1-day $27^{\circ} \mathrm{C}$ libraries (Figure 8). Consistent with the clone library analysis, the profile from CCA at $32^{\circ} \mathrm{C}$ was distinct from the other samples after 7 days. However, the samples from CCA at $32{ }^{\circ} \mathrm{C}$ after 2 days did not generate different banding profiles to the samples from the lower temperatures. Although the CCA at $31^{\circ} \mathrm{C}$ for 7 days clustered with the 2- and 7-day samples from the lower temperatures, the $31^{\circ} \mathrm{C}-\mathrm{CCA}$ profile from the recovery period did clearly separate from the other samples (Figure 8).

In terms of diversity and evenness of the clone libraries, there was no apparent trend with temperature. Rarefaction analysis indicated that between $71 \%$ and $88 \%$ of the diversity was sampled in the various CCA biofilm treatments, but only $23-36 \%$ of the diversity was sampled in the sediment biofilm libraries (Table 2; Supplementary Figures 2a and b). The most diverse CCA library using both Chao1 and Ace indices was the 7 -day $29^{\circ} \mathrm{C}$ library followed by the 7 -day $31^{\circ} \mathrm{C}$ and 2 -day $27^{\circ} \mathrm{C}$ libraries (Table 2). The lowest-diversity CCA library was the 7-day $27^{\circ} \mathrm{C}$ treatment.

To assess how CCA eukaryotic biofilms were affected by temperature, DGGE was performed with universal 18S rRNA gene primers. Although more bands were detected in the 7 days and recovery samples (Supplementary Figure 5), there was no trend associated with temperature treatment of the CCA samples. This was further illustrated with principle components analysis revealing no clear separation of the samples according to temperature treatment (Supplementary Figure 6). Similarly, 16S rRNA gene DGGE analysis of the seawater samples from each of the temperature treatments revealed a greater number of bands in the 7 days and recovery time points (Supplementary Figure 7), but no clear effect of temperature. Principle components analysis of this DGGE revealed clear clustering of the microbial communities according to sampling time rather than treatment temperature (Supplementary Figure 8).

\section{Discussion}

This study revealed that the CCA $N$. fosliei, and its associated microbial communities do not tolerate SSTs of $32{ }^{\circ} \mathrm{C}$, only $2-4{ }^{\circ} \mathrm{C}$ above the mean maximum annual SST at Davies Reef where the CCA was collected (http://data.aims.gov.au/awsqaqc/do/ start.do). After 7 days at $32{ }^{\circ} \mathrm{C}$, the CCA exhibited clear signs of stress, including visual evidence of bleaching, a reduction in maximum quantum yield and a large shift in microbial community structure involving a move away from Alphaproteobacteria towards a dominance by Bacteroidetes. A recovery in photosynthetic capacity $\left(F_{\mathrm{v}} / F_{\mathrm{m}}\right)$ was observed in CCA exposed to $31{ }^{\circ} \mathrm{C}$ following 7 days of recovery (at $27^{\circ} \mathrm{C}$ ); however CCA exposed to $32{ }^{\circ} \mathrm{C}$ did not appear to recover during this time as evidenced by the rapid growth of endolithic green algae. A reduction in the ability of $N$. fosliei to induce coral larval metamorphosis at $32^{\circ} \mathrm{C}$ accompanied the changes in microbiology, pigmentation and photophysiology of the CCA. This is the first experimental evidence to demonstrate how thermal stress on coralline algae may influence coral recruitment and this may have implications for reef regeneration and recovery from climate-related mortality events.

The thermal threshold for bleaching in N. fosliei was similar to that of the GBR corals A. formosa, A. elseyi and Pocillopora damicornis (Berkelmans and Willis, 1999). The visible bleaching at $31^{\circ} \mathrm{C}$ and $32{ }^{\circ} \mathrm{C}$ was preceded by drops in $F_{\mathrm{v}} / F_{\mathrm{m}}$, which declined by $53 \%$ and $80 \%$, respectively after 7 days compared with CCA maintained at $27^{\circ} \mathrm{C}$. This reduction in $F_{\mathrm{v}} / F_{\mathrm{m}}$ indicates potential chronic photoinactivation, caused by thermal and oxidative damage to (or loss of) the D1 reaction centre in PSII (Warner et al., 1999). In a recent study, the shallow CCA species Porolithon onkodes from the GBR also demonstrated partial bleaching following exposure to elevated SST (Anthony et al., 2008). N. fosliei is abundant on the GBR at depths of 5-10 m, and may be less adapted to cope with increases in SST. The loss of pigmentation in P. onkodes was accompanied by reductions in productivity (Anthony et al., 2008), possibly because of chronic photoinactivation as 


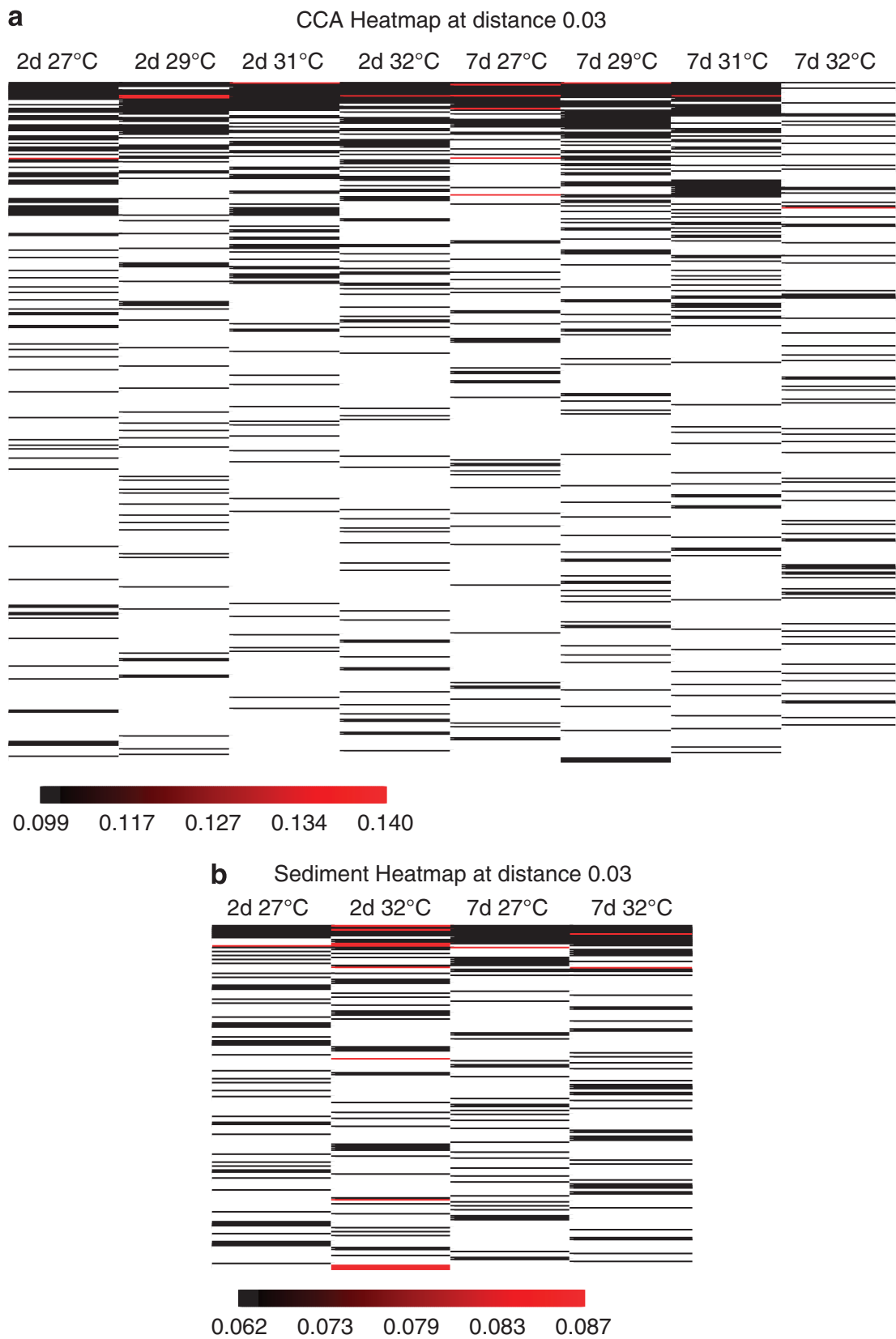

Figure 6 OTU heat maps generated with a distance of 0.03 for CCA (a) and sediment (b) libraries. The 7-day $32{ }^{\circ} \mathrm{C}$ CCA library is a distinct outlier and there is greater variability between the CCA derived libraries than the sediment-derived libraries.

described here. The slow recovery in $F_{\mathrm{v}} / F_{\mathrm{m}}$ of CCA exposed to $31{ }^{\circ} \mathrm{C}$ in this study is consistent with the gradual repair of PSII damaged by thermal stress; however, this could not be confirmed in CCA discs exposed to $32{ }^{\circ} \mathrm{C}$ because of the presence of endolithic green algae under the surface of the CCA.

The microbial communities associated with CCA shifted at both $31^{\circ} \mathrm{C}$ and $32{ }^{\circ} \mathrm{C}$, but the shift was much more rapid at the higher temperature. Although the Alphaproteobacteria clearly dominates the CCA microbial community at ambient temperatures, there is a distinct shift towards the Bacteroidetes in CCA exposed to $32{ }^{\circ} \mathrm{C}$ for 7 days.
The primary Alphaproteobacteria strain to be lost from CCA at $32{ }^{\circ} \mathrm{C}$ had highest sequence similarity to a described coral symbiont. The role of this microbe within the CCA biofilm has not been ascertained, but there is some evidence that the loss of bacterial symbionts due to elevated SST can have significant implications on the health of the host (Webster et al., 2008a). The increase in Bacteroidetes is consistent with previous studies of marine organisms subjected to stressors such as elevated SST or disease. In the GBR sponge Rhopaloeides odorabile, the Bacteroidetes were absent from sponges maintained at temperatures up to $31{ }^{\circ} \mathrm{C}$ but dominated the 


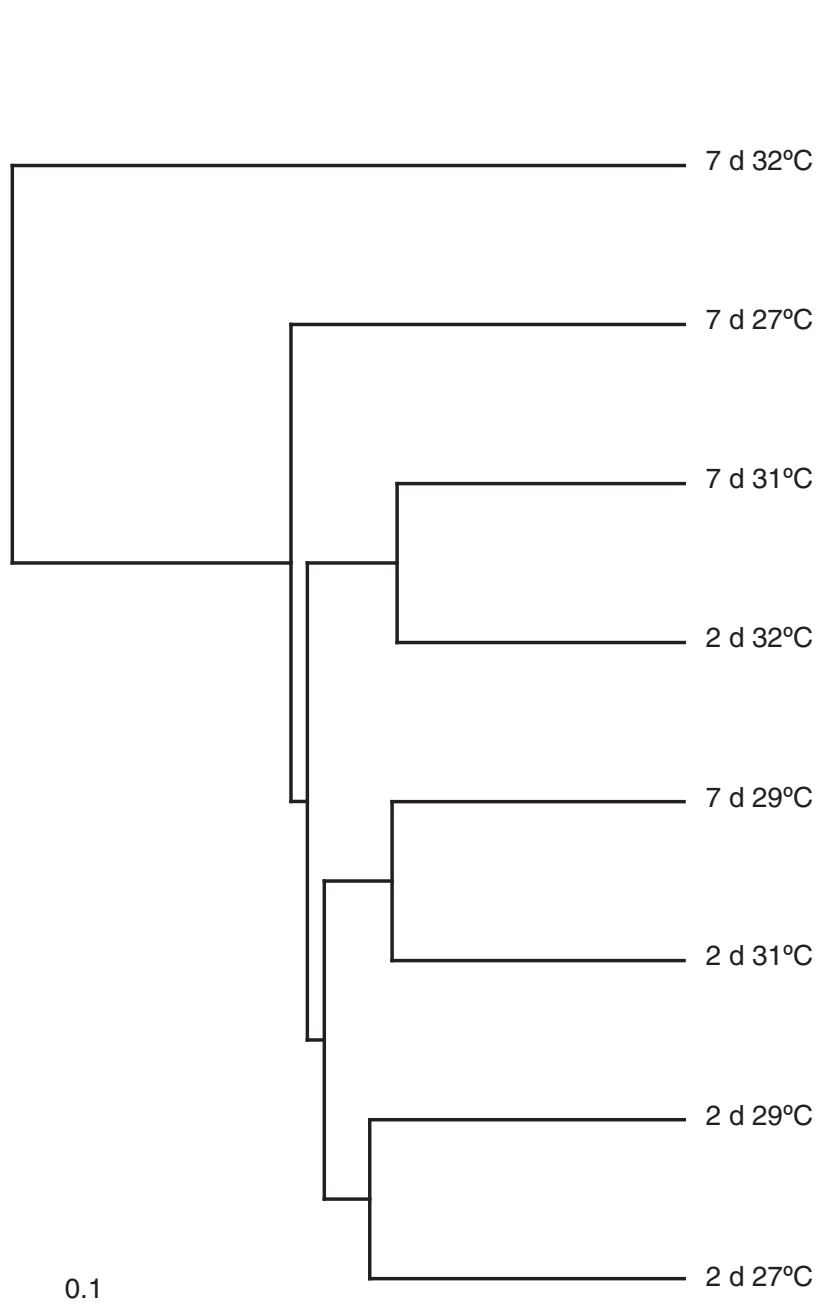

Figure 7 Community tree constructed from an OTU assignment using a distance of 0.03 . The cluster analysis shows similarity between each of the CCA-derived 16S rRNA gene clone libraries.

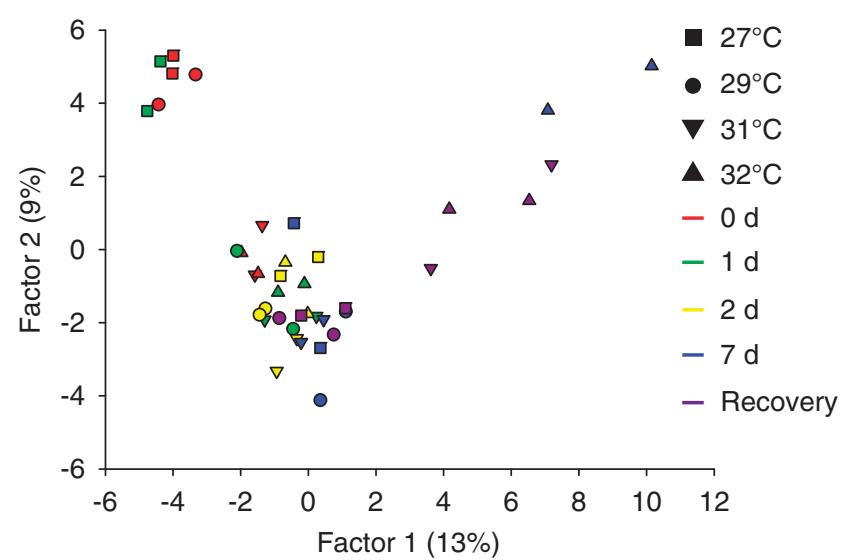

Figure 8 Principal components analysis of CCA bacterial community composition at each of the temperature treatments. DGGE banding pattern data generated with primers specific to the Alphaproteobacteria and Bacteroidetes groups.

microbial community in sponges exposed to $33^{\circ} \mathrm{C}$ (Webster et al., 2008a). Similarly, diseased corals and sponges host a much greater abundance of Bacteroidetes than their healthy counterparts (Frias-Lopez et al., 2002; Pantos and Bythell, 2006;
Webster et al., 2008b). The closest relative to the Bacteroidetes sequence that became highly abundant at $32{ }^{\circ} \mathrm{C}$ was a novel marine Flavobacteria with anti-oxidative properties (Shindo et al., 2007). The Bacteroidetes are diverse and abundant in the marine ecosystem (O'Sullivan et al., 2006) and are major utilizers of high-molecular mass dissolved organic matter (Cottrell and Kirchman, 2000). For this reason, they are often abundant in nutrient-rich waters in which biomacromolecules accumulate (Reichenbach, 1989). It is possible that heat-stressed or decaying CCA cells provided an abundant and varied source of nutrients for these bacteria, resulting in an increased abundance of Bacteroidetes in the 7-day $32{ }^{\circ} \mathrm{C}$ samples. The increased abundance of a Deltaproteobacteria in CCA exposed to $32^{\circ} \mathrm{C}$ for 7 days is consistent with studies showing an increase in Delatproteobacteria in diseased corals and sponges. The closest described relative to this sequence was a Desulfovibrio spp. retrieved from an unpublished study of diseased and healthy corals. Closely related Desulfovibrio spp. have been implicated in coral black band disease (AY750147) and in black patch syndrome affecting the sponge Alpysina aerophoba (EU267167), (Webster et al., 2008b). An alternative explanation for the community differences observed in CCA at $32{ }^{\circ} \mathrm{C}$ may be due to microbes associated with the green endolithic algae that colonised the bleached CCA surface after 5 days. Future research is urgently required to assess the implications of these microbial shifts to CCA health and coral recruitment.

The bacterial biofilms on the surface of CCA exhibited a different response to elevated temperature than bacterial communities associated with reef sediments, which were largely conserved at all temperatures. In addition, the microbial community of the seawater from each of the CCA tanks showed no correlation to the treatment temperature. This indicates that either (1) the thermal stress response of the host CCA contributes to the shift in the biofilm community or (2) the composition of the biofilm on the surface of CCA is more sensitive to environmental change (either because of a more specific association, as may occur in symbiosis, or due to the initial CCA bacterial community composition containing more temperature-sensitive biofilm species). For the large number of marine invertebrates that settle and metamorphose in response to sediment biofilms, this community stability suggests that these organisms may be less affected by increasing SST than those that rely on more sensitive bacterial biofilms associated with biotic surfaces such as CCA. DGGE analysis showed that the CCA biofilm community was unable to recover its original composition within 7 days once the SST had been returned to ambient. It is possible that the prolonged temperature stress (as occurred in the 7-day experiment) caused a phase shift in the microbial community to an alternate stable state. Alternatively, the impact of elevated SST on CCA 
Table 2 Diversity indices calculated from sequences of 16S rRNA genes using a 97\% sequence similarity threshold

\begin{tabular}{|c|c|c|c|c|c|c|}
\hline Treatment & Total clones & Unique OTUs & Diversity sampled (\%) & Shannon-Weaver & Chao1 & Ace \\
\hline CCA $27^{\circ} \mathrm{C} 2$ days & 155 & 63 & 81 & 3.69 & 98 & 111 \\
\hline CCA $29^{\circ} \mathrm{C} 2$ days & 135 & 53 & 80 & 3.48 & 76 & 95 \\
\hline CCA $31^{\circ} \mathrm{C} 2$ days & 144 & 53 & 79 & 3.30 & 82 & 105 \\
\hline CCA $32^{\circ} \mathrm{C} 2$ days & 171 & 51 & 88 & 3.21 & 76 & 77 \\
\hline CCA $27^{\circ} \mathrm{C} 7$ days & 117 & 50 & 81 & 3.54 & 66 & 82 \\
\hline CCA $29^{\circ} \mathrm{C} 7$ days & 157 & 70 & 72 & 3.73 & 174 & 179 \\
\hline CCA $31{ }^{\circ} \mathrm{C} 7$ days & 155 & 63 & 71 & 3.41 & 98 & 116 \\
\hline CCA $32{ }^{\circ} \mathrm{C} 7$ days & 142 & 51 & 76 & 3.23 & 93 & 126 \\
\hline Sed $27^{\circ} \mathrm{C} 2$ days & 65 & 54 & 29 & 3.90 & 234 & 296 \\
\hline Sed $32^{\circ} \mathrm{C} 2$ days & 62 & 55 & 23 & 3.97 & 196 & 244 \\
\hline Sed $27^{\circ} \mathrm{C} 7$ days & 69 & 55 & 36 & 3.91 & 165 & 212 \\
\hline Sed $32^{\circ} \mathrm{C} 7$ days & 64 & 54 & 29 & 3.93 & 202 & 215 \\
\hline
\end{tabular}

Abbreviations: CCA, crustose coralline algae; OTU, operational taxonomic unit, Sed, sediment.

health may have adversely affected the ability of the CCA immune system to regulate microbial colonisation and growth.

This study has highlighted the importance of using multiple methods for assessing microbial community responses. DGGE facilitated the analysis of large numbers of replicates, whereas clone libraries were utilised to explore the composition of the shifting microbes. LIBSHUFF analysis of $16 \mathrm{~S}$ rRNA clone libraries found many more differences than the DGGE analysis (for example, microbial community differences in libraries at $27^{\circ} \mathrm{C}$ and $\left.29^{\circ} \mathrm{C}\right)$. DGGE with the $r p o B$ gene was unable to distinguish the microbial shift that occurred at $32{ }^{\circ} \mathrm{C}$ after 7 days. The results from $16 \mathrm{~S}$ rRNA gene clone libraries and 16S rRNA gene DGGE with Alphaproteobacteria and Bacteroidetes-specific primers were largely consistent, although the DGGE did not detect the shift at $32{ }^{\circ} \mathrm{C}$ after 2 days. This is possibly because of the fact that only the predominant microbes will be detected with this type of fingerprinting approach, whereas deep clone sequencing can assess more subtle effects or the response of the 'rarer' microbial community members.

Interestingly, the elevated SST did not have an impact on microbial community diversity or evenness. This is in contrast to other studies using marine models in which stressors such as SST (Webster et al., 2008a) eutrophication (Uthicke and McGuire, 2007) or disease (Cooney et al., 2002; Pantos et al., 2003; Pantos and Bythell, 2006; Webster et al., 2008b) cause a shift (either an increase or decrease) in microbial diversity. A reduced microbial diversity was observed in sediments from an inshore reef with high inorganic carbon compared with a nearby offshore reef (Uthicke and McGuire, 2007); however, a 53\% increase in bacterial diversity was detected in a GBR sponge at $33^{\circ} \mathrm{C}$ compared with the sponge microbial community at $27^{\circ} \mathrm{C}$.

A significant reduction in coral metamorphosis occurred in response to CCA that had been exposed to $32{ }^{\circ} \mathrm{C}$ for 7 days. The reduction in inductive capacity at $32{ }^{\circ} \mathrm{C}$ may be due to a number of factors including: (1) the loss of a critical microbial species on the surface of CCA that is directly responsible for the induction of metamorphosis (Johnson and Sutton, 1994), (2) the loss of a microbial species required to enable the CCA to produce an inducer for larval metamorphosis (disruption of a shared metabolic pathway), (3) the inhibition of a biochemical process within the CCA alone to produce an indicator for larval metamorphosis, (4) the inhibition of larval metamorphosis by specific microbes (Dobretsov and Qian, 2004), or (5) an interaction (for example, pathogenicity) between the microbial community and the CCA (for instance Deltaproteobacteria and Desulfovibrio in CCA exposed to $32{ }^{\circ} \mathrm{C}$ have been identified in association with diseased corals and sponges).

$N$. fosliei is a key reef-building primary producer on the GBR and other coral reefs (Harrington et al., 2004). The low-thermal tolerance of this species is of concern as CCA are especially vulnerable to increases in ocean acidification $\left(\mathrm{pCO}_{2}\right)$, which is projected to intensify under continued conditions of climate change (Kuffner et al., 2008). Combinations of elevated SSTs and acidification further enhance CCA bleaching, productivity and reduce calcification (Anthony et al., 2008; Martin and Gattuso, 2009). Furthermore, CCA (including N. fosliei) are critical to the recruitment of many coral species (Heyward and Negri, 1999; Harrington et al., 2004), including many Acropora species, which often dominate reef habitats of the GBR. Any reduction in the capacity of CCA to induce coral larval metamorphosis by thermal stress, as described here, would clearly add to the pressures already faced by corals under conditions of a changing climate. Although shifts in CCA-associated microbial communities correlate with reductions in coral larval metamorphosis, further work is required to determine the role of microbiology in the recruitment process. 


\section{Acknowledgements}

We thank Dr Sven Uthicke for helpful discussions about data analysis and Dr Ken Wasmund for assisting with sample processing.

\section{References}

Anthony KRN, Kline DI, Diaz-Pulido G, Dove S, Hoegh-Guldberg O. (2008). Ocean acidification causes bleaching and productivity loss in coral reef builders. Proc Natl Acad Sci 105: 17442-17446.

Berkelmans R, Willis BL. (1999). Seasonal and local spatial patterns in the upper thermal limits of corals on the inshore Central Great Barrier Reef. Coral Reefs 18: 219-228.

Cooney RP, Pantos O, Le Tissier MD, Barer MR, O’Donnell AG, Bythell JC. (2002). Characterization of the bacterial consortium associated with black band disease in coral using molecular microbiological techniques. Environ Microbiol 4: 401-413.

Cottrell MT, Kirchman DL. (2000). Natural assemblages of marine proteobacteria and members of the CytophagaFlavobacter cluster consuming low- and high-molecular weight dissolved organic matter. Appl Environ Microbiol 66: 1692-1697.

Dahllöf I, Baillie H, Kjelleberg S. (2000). rpoB-based microbial community analysis avoids limitations inherent in 16S rRNA gene intraspecies heterogeneity. Appl Environ Microbiol 66: 3376-3380.

Dobretsov S, Qian PY. (2004). The role of epibotic bacteria from the surface of the soft coral Dendronephthya sp. in the inhibition of larval settlement. J Exp Mar Biol Ecol 299: 35-50.

Felsenstein J. (1993). PHYLIP (Phylogenetic Inference Package) Version 3.5c. Department of Genetics, University of Washington: Seattle, WA.

Ferris MJ, Muyzer G, Ward DM. (1996). Denaturing gradient gel electrophoresis profiles of $16 \mathrm{~S}$ rRNAdefined populations inhabiting a hot spring microbial mat community. Appl Environ Microbiol 62: 340-346.

Fierer N, Jackson JA, Bilgalys R, Jackson RB. (2005). Assessment of soil microbial community structure by use of taxon-specific quantitative PCR assays. Appl Environ Microbiol 71: 4117-4120.

Frias-Lopez J, Zerkle AL, Bonheyo GT, Fouke BW. (2002). Partitioning of bacterial communities between seawater and healthy, black-band diseased, and dead coral surfaces. Appl Environ Microbiol 68: 2214-2228.

Galbary D, Veltkamp CJ. (1980). Observations on Mesophyllum lichenoides (Corallinaceae, Rhodophyta) with scanning electron microscope. Phycologia 19: 49-53.

Garland CD, Cooke SL, Grant JF, McMeekin TA. (1985). Ingestion of the bacteria on and the cuticle of crustose (non-articulated) coralline algae by post-larval and juvenile abalone (Haliotis ruber leach) from Tasmanian waters. J Exp Mar Biol Ecol 91: 137-149.

Gelsomino A, Cacco G. (2006). Compositional shifts of bacterial groups in a solarised and amended soil as determined by denaturing gradient gel electrophoresis. Soil Biol Biochem 38: 91-102.

Genty B, Briantais JM, Baker NR. (1989). The relationship between the quantum yield of photosynthetic electron transport and quenching of chlorophyll fluorescence. Biochim Biophys Acta 990: 87-92.

Harrington LM, Fabricius K, De'ath G, Negri A. (2004). Recognition and selection of settlement substrata determine post-settlement survival in corals. Ecology 85: 3428-3437.

Heyward AJ, Negri AP. (1999). Natural inducers for coral larval metamorphosis. Coral Reefs 18: 273-279.

Huber T, Faulkner G, Hugenholtz P. (2004). Bellerophon: a program to detect chimeric sequences in multiple sequence alignments. Bioinformatic Applications Note 20: $2317-2319$.

Huggett MJ, Williamson JE, de Nys R, Kjelleberg S, Steinberg PD. (2006). Settlement of the common Australian sea urchin Heliocidaris erythrogramma in response to bacteria from the surface of coralline algae. Oecologia 149: 604-619.

Huys G, Vanhoutte T, Vandamme P. (2008). Applications of sequence-dependent electrophoresis fingerprinting in exploring biodiversity and population dynamics of human intestinal microbiota: What can be revealed? Interdiscipl Perspect Infect Dis 2008: 26pp.

IPCC. (2007). Climate Change 2007: The Physical Basis. Contribution of Working Group I to the Fourth Assessment Report of the Intergovernmental Panel on Climate Change. Cambridge University Press Cambridge: UK.

Johnson CR, Muir DG, Reysenbach A-L. (1991). Characteristic bacteria associated with the surfaces of coralline algae: a hypotheses for bacterial induction of marine invertebrate larvae. Mar Ecol Prog Ser 74: 281-294.

Johnson CR, Sutton DC. (1994). Bacteria on the surface of crustose coralline algae induce metamorphosis of the crown of thorns starfish Acanthaster planci. Mar Biol 120: $305-310$.

Jones RJ, Muller J, Haynes D, Schreiber U. (2003). Effects of herbicides diuron and atrazine on corals of the Great Barrier Reef, Australia. Mar Ecol Prog Ser 251: 153-167.

Kuffner IB, Andersson AJ, Jokiel PL, Rodgers K, Mackenzie FT. (2008). Decreased abundance of crustose coralline algae due to ocean acidification. Nat Geosci 1: 114-117.

Lawrence JR, Chenier MR, Roy R, Beaumier D, Fortin N, Swerhone GD et al. (2004). Microscale and molecular assessment of impacts of nickel, nutrients, and oxygen level on structure and function of river biofilm communities. Appl Environ Microbiol 70: 4326-4339.

Lewis TE, Garland CD, McMeekin TA. (1985). The bacterial biota on crustose (nonarticulated) coralline algae from Tasmanian waters. Microb Ecol 11: 221-230.

Ludwig W, Strunk O, Klugbauer S, Klugbauer N, Weizenegger M, Neumaier J et al. (1998). Bacterial phylogeny based on comparative sequence analysis. Electrophoresis 19: 554-568.

Maidak BL, Cole JR, Parker Jr CT, Garrity GM, Larsen N, Li $B$ et al. (1999). A new version of the RDP (Ribosomal Database Project). Nucleic Acids Res 27: 171-173.

Marchesi JR, Sato T, Weightman AJ, Martin TA, Fry JC, Hiom SJ et al. (1998). Design and evaluation of useful bacterium-specific PCR primers that amplify genes coding for bacterial 16S rRNA [published erratum appears in Appl Environ Microbiol 1998 Jun; 64: 2333]. Appl Environ Microbiol 64: 795-799.

Martin S, Gattuso JP. (2009). Response of Mediterranean coralline algae to ocean acidification and elevated temperature. Glob Change Biol 15: 2089-2100. 
Meyer-Reil L-A, Koster M. (2000). Eutrophication of marine waters: effects on benthic microbial communities. Mar Pollut Bull 41: 255-263.

Morse ANC, Iwao K, Baba M, Shimoike K, Hayashibara T, Omori M. (1996). An ancient chemosensory mechanism brings new life to coral reefs. Biol Bull 191: 149-154.

Morse DE, Hooker N, Morse ANC, Jensen RA. (1988). Control of larval metamorphosis and recruitment in sympatric agariciid corals. J Exp Mar Biol Ecol 116: 193-217.

Morse DE, Morse AN, Raimondi PT, Hooker N. (1994). Morphogen-based chemical flypaper for Agaricia humilis coral larvae. Biol Bull 186: 172-181.

Negri AP, Heyward AJ. (2000). Inhibition of fertilization and larval metamorphosis of the coral Acropora millepora (Ehrenberg, 1834) by petroleum products. Mar Pollut Bull 41: 420-427.

Negri AP, Webster NS, Hill RT, Heyward AJ. (2001). Metamorphosis of broadcast spawning corals in response to bacteria isolated from crustose algae. Mar Ecol Prog Ser 223: 121-131.

O’Sullivan LA, Rinna J, Humphreys G, Weightman AJ, Fry JC. (2006). Culturable phylogenetic diversity of the phylum 'Bacteroidetes' from river epilithon and coastal water and description of novel members of the family Flavobacteriaceae: Epilithonimonas tenax gen. nov., sp. nov. and Persicivirga xylanidelens gen. nov., sp. nov. Int J Syst Evol Microbiol 56: 169-180.

Osmond CB, Anderson JM, Ball MC, Egerton JJG. (1999). Compromising efficiency: the molecular ecology of light resource utilisation in terrestrial plants. In: Scholes C, Baker M (eds). Advances in Physiological Plant Ecology. Blackwell: Oxford.

Pantos O, Cooney RP, Le Tissier MD, Barer MR, O’Donnell AG, Bythell JC. (2003). The bacterial ecology of a plague-like disease affecting the Caribbean coral Montastrea annularis. Environ Microbiol 5: 370-382.

Pantos O, Bythell JC. (2006). Bacterial community structure associated with white band disease in the elkhorn coral Acropora palmata determined using culture independent $16 \mathrm{~S}$ rRNA techniques. Dis Aquat Org 69: 79-88.

Reichenbach H. (1989). Nonphotosynthetic, nonfruiting gliding bacteria. Genus 1. Cytophaga Winogradsky 1929, 577AL, emend. In: Staley JT, Bryant MP, Pfennig N, Holt JG (eds). Bergey's Manual of Systematic Bacteriology. Baltimore.

Rodriguez SR, Ojeda FP, Inestrosa C. (1993). Settlement of benthic marine invertebrates. Mar Ecol Prog Ser 97: 193-207.

Schloss PD, Handelsman J. (2005). Introducing DOTUR, a computer program for defining operational taxonomic units and estimating species richness. Appl Environ Microbiol 71: 1501-1506.

Schloss PD, Larget BR, Handelsman J. (2004). Integration of microbial ecology and statistics: a test to compare gene libraries. Appl Environ Microbiol 70: 5485-5492.
Schloss PD, Westcott SL, Ryabin T, Hall JR, Hartmann M, Hollister EB et al. (2009). Introducing mothur: open-source, platform-independent, community-supported software for describing and comparing microbial communities. Appl Environ Microbiol 75: 7537-7541.

Shindo K, Kikuta K, Suzuki A, Katsuta A, Kasai H, Yasumoto-Hirose $\mathrm{M}$ et al. (2007). Rare carotenoids, (3R)-saproxanthin and (3R,2'S)-myxol, isolated from novel marine bacteria (Flavobacteriaceae) and their antioxidative activities. Appl Microbiol Biotech 74: 1350-1357.

Sunagawa S, Woodley CM, Medina M. (2010). Threatened corals provide underexplored microbial habitats. PLoS One 5: e9554.

Uthicke S, McGuire K. (2007). Bacterial communities in Great Barrier Reef calcareous sediments: contrasting $16 \mathrm{~S}$ rDNA libraries from nearshore and outer shelf reefs. Est Coast Shelf Sci 72: 188-200.

Warner ME, Fitt WK, Schmidt GW. (1999). Damage to photosystem II in symbiotic dinoflagellates: a determinant of coral bleaching. P Natl Acad Sci 96: 8007-8012.

Webster NS, Battershill CN, Negri AP. (2006). Recruitment of Antarctic marine eukaryotes onto artificial surfaces. Polar Biol 30: 1-10.

Webster NS, Cobb RE, Negri AP. (2008a). Temperature thresholds for bacterial symbiosis with a sponge. ISME J 2: 830-842.

Webster NS, Hill RTH. (2007). Vulnerability of marine microbes on the Great Barrier Reef to climate change. In: Johnson JE, Marshall PA (eds). Climate Change and the Great Barrier Reef. Great Barrier Reef Marine Park Authority and Australian Greenhouse Office: Australia, Townsville.

Webster NS, Smith LD, Heyward AJ, Watts JE, Webb RI, Blackall LL et al. (2004). Metamorphosis of a scleractinian coral in response to microbial biofilms. Appl Environ Microbiol 70: 1213-1221.

Webster NS, Xavier JR, Freckelton M, Motti CA, Cobb R. (2008b). Shifts in microbial and chemical patterns within the marine sponge Aplysina aerophoba during a disease outbreak. Environ Microbiol 10: 3366-3376.

White TJ, Bruns T, Lee S, Taylor J. (1990). Amplification and direct sequencing of fungal ribosomal RNA genes for phylogenetics. In: Innis MA, Gelfand $\mathrm{DH}$, Sninsky JJ, White TJ (eds). PCR Protocols: A Guide to Methods and Applications. Academic Press: New York, pp 315-322.

Wieczorek SK, Todd CD. (1997). Inhibition and facilitation of bryozoan and ascidian settlement by natural multispecies biofilms: effects of film age and the roles of active and passive larval attachment. Mar Biol 128: $463-473$.

Wieczorek SK, Todd CD. (1998). Inhibition and facilitation of settlement of epifaunal marine invertebrate larvae by microbial biofilm cues. Biofouling 12: 81-118.

Supplementary Information accompanies the paper on The ISME Journal website (http://www.nature.com/ismej) 